\title{
Flowering and seeding patterns in pure and mixed Nothofagus forests in Southern Patagonia
}

\author{
Mónica Toro Manríquez ${ }^{1 *}$, Luciana Mestre ${ }^{1}$, María Vanessa Lencinas ${ }^{1}$, Álvaro Promis², \\ Guillermo Martínez Pastur ${ }^{1}$ and Rosina Soler ${ }^{1}$
}

\begin{abstract}
Introduction: Variation in reproductive phenology among species is an important mechanism for maintaining species coexistence. In mixed forests, the impact of limiting (biotic and abiotic) factors on tree reproductive success regulates the maintenance of species in balanced proportions or the conversion towards monospecific forests. This study offer a significant first approach to the reproductive phenology of mixed forests, assessing flowering, seeding and loss factors on reproductive success in three forest types (pure deciduous Nothofagus pumilio (Np), evergreen Nothofagus betuloides (Nb) and mixed (M) forests), comparing also between two geographical locations (coast and mountain), during one growing season.
\end{abstract}

Results: Flowering falling started early in $\mathrm{Np}$. Seed fall occurred first and more concentrated in $\mathrm{Np}$, while in $\mathrm{Nb}$, it was progressive during autumn. Phenology in $\mathrm{M}$ combined both patterns, but with better reproductive performance of both species. Seed production was greater in $\mathrm{Nb}\left(42,900,000 \mathrm{ha}^{-1}\right)$ than in $\mathrm{Np}\left(710,000 \mathrm{ha}^{-1}\right)$, while M presented intermediate values $\left(31,900,000 \mathrm{ha}^{-1}\right)$. Abortion was greatest in $\mathrm{Np}$ (19\% of female flowers and $10 \%$ of immature fruits), while fruit predation was low (7-9\%) in all forest types. Empty seed was the main loss factor, but with low net values for each species in M. Regarding geographical location, sea proximity generated a quick starting of the growing season in coast compared to mountain sites. However, we detected forest types $\times$ location interactions in flowering and seeding patterns (e.g. in male flower production and in empty and viable seeds), with differences in species response according to location.

Conclusions: Both deciduous and evergreen species have reproductive advantages in mixed compared to pure forests. However, mixed were more similar to pure evergreen forests in their reproductive traits and the incidence of the limiting factors. The study of only one growing season does not allow us to conclude whether mixed forests are stable communities, but we contribute to understand the roles of reproductive phenology in mixed forest dynamics.

Keywords: Broadleaved, Mixed forest, Geographical location, Leaf habit, Reproductive phenology, Seed quality

\section{Introduction}

Phenology is a dominant and crucial aspect of plant ecology, from the scale of individuals to whole ecosystems (Cleland et al. 2007). Variation in reproductive phenology (flowering and seeding pattern) among species is an important mechanism for maintaining species coexistence in diverse plant communities. The relative

\footnotetext{
* Correspondence: monicatm@cadic-conicet.gob.ar

${ }^{1}$ National Scientific and Technical Research Council (CONICET), Austral Center for Scientific Research (CADIC-CONICET), Houssay 200, 9410 Ushuaia, Tierra del Fuego, Argentina

Full list of author information is available at the end of the article
}

role of individual selection factors, such as weather, light and water availability, the abundance of herbivorous insects and fruit disperser availability, regulates differences between the reproductive phenology patterns within a community.

Several studies suggest that phenology plays an important role in fitness (i.e. reproduction and survival) and therefore in species distribution (Chuine 2010). Many coexisting species that differ in leaf habit and functional attributes adjust their reproductive abilities (Pérez-Ramos et al. 2014) resulting in different 
phenological patterns at landscape and community levels of ecological organization. For instance, in mixed forest, the natural dynamic of recruitment is a function not only of the completion of the annual reproductive cycle (flowering, seeding and seedling establishment) of tree species and their accomplished phenology but also of the interactions with other organisms, climate and natural disturbances (Espelta et al. 2009; Schoolmaster 2013; Bergeron et al. 2014; Dreiss and Volin 2013). Such interactions might determine a shift from mixed forest to stands dominated only by one or few species (Bergeron et al. 2014), as part of the natural succession. Even more, in mixed forests shaped by only two species, it could determine its conversion to monospecific forests over time. Mixed temperate forests that combine broadleaved deciduous and broadleaved evergreen angiosperm trees, such oak (Quercus spp.) or beeches (Nothofagus spp.), exhibit a combination of phenological features (e.g. litter fall from deciduous trees occurs massively during autumn, while litter from evergreen trees fall continuously throughout the year). This determines differences among mixed stands and those where the same tree species dominate the overstory. For instance, natural spontaneous abortion provoked by frost or heavy rain in pure deciduous stands during spring/early summer (Riveros et al. 1995) could be damped in mixed stands due to the partial (evergreen) canopy cover; higher variety of food resource (e.g. different seed sizes and shapes) in mixed stands can attract more fruit/seed predators (Leishman et al. 2000) resulting in a higher predation rate than in pure stands. There are many ecological features of mixed forest that we ignore, and our understanding of how compositional or structural drivers shape species distribution is still far from complete.

Moreover, the contemporary climate change has resulted in widespread and ongoing shifts in phenology across many taxa and within varied geographic regions (Cleland et al. 2007) because temperature influences the timing of development, both alone and through interactions with other cues (e.g. frost dates, growing season length). Such shifts in species' phenologies can affect the specific composition, and it can result in disruptions to the ecosystem processes and functioning (Denny et al. 2014).

The genus Nothofagus has been a model case for studies of biogeography, masting ecology and adaptation to climate change, among others (Swenson et al. 2001; Kelly et al. 2002; Hertel et al. 2008). However, it is largely unknown how is the reproductive performance of tree species in mixed structures that allow their coexistence. Moreover, these mixed temperate forests offer a valuable opportunity for studying phenology and reproductive success of tree coexisting species. The general objectives of this study were to understand of the possible roles of reproductive phenology and reproductive success in the dynamic of mixed forests and to evaluate whether there is stability of the mixed structure or replacement of one species by another. For this purpose, we assessed reproductive phenological patterns (flowering and seeding) in pure deciduous Nothofagus pumilio and pure broadleaved-evergreen Nothofagus betuloides forests and compare it with mixed forests during one growing season. Also, we identified and evaluated the incidence of different loss factors that could shape the reproductive success: premature abscission of reproductive structures, pre-dispersal fruit and seed predation by insects and birds and mature seed quality. Since these mixed forest communities occur on a wide geographic gradient (different elevation and climatic regime controlling photoperiod), we compare reproductive phenology and success in two typical geographical locations: coastal and mountain sites.

To address this research, we compared the following: (1) the reproductive phenology and loss factors affecting the flowering and seeding success in pure $N$. betuloides and N. pumilio forests, (2) the reproductive phenology of each species growing in pure with mixed forests, and (3) reproductive phenology and loss factors of each species of pure and mixed forests in different geographic location. Native forests in Tierra del Fuego Island grow naturally under extreme environmental conditions, controlled by Atlantic Ocean, the influence of the Antarctic climate and the Andes Mountains, by generating strong climate gradients at regional levels (Kreps et al. 2012). At these high latitudes, tree growth is most sensitive to climatic conditions (Hertel et al. 2008; Massaccesi et al. 2008; Ivancich et al. 2012), and therefore, a shift in community composition forced by climate change would be more evident. This study will contribute to understanding of the possible roles of reproductive phenology for detecting shifts in forest communities between pure and mixed forests under natural dynamics and the current climate regime.

\section{Methods}

\section{Natural history of Nothofagus forests}

Nothofagus is a classic Gondwanan genus and is quantitatively important in many southern forested landscapes. High seed fall variation within this genus is a significant driver of animal population cycles (Choquenot and Ruscoe 2000). It is thought that flowering in Nothofagus is triggered by warm dry summers during the previous year (Schauber et al. 2002; Bahamonde et al. 2011) with Nothofagus populations showing considerable withinand between-species synchrony over spatial scales in excess of several hundred kilometres (Schauber et al. 2002). In the southern hemisphere, Nothofagus genus 
(Nothofagaceae) is represented by deciduous and evergreen trees. For example, the deciduous N. pumilio and the broadleaved-evergreen $N$. betuloides are two contrasting leaf habit species that coexist along Tierra del Fuego Island, conforming mixed old-growth forest in both coastal and mountain sites. These tree species are co-dominant at the canopy level of these mixed forests (Gutiérrez 1994) and could exhibit different proportions of mixed trees.

$N$. pumilio (lenga) forests are the main commercial woodlands in southern Argentina and Chile. It is a deciduous broadleaved species that grows mainly not only in pure stands but also in mixed stands with the evergreen N. betuloides (guindo) species (Cruz et al. 2007). N. pumilio is a medium-high tree reaching up to $30 \mathrm{~m}$ in height (Martínez Pastur et al. 1997) and up to $1.7 \mathrm{~m}$ DBH in the better site qualities. Litter fall of this species occurs massively, and the fruit contains a single large seed (5-7 mm length). On the other hand, $N$. betuloides can reach $30-35 \mathrm{~m}$ in height and up to $2 \mathrm{~m} \mathrm{DBH}$ in Tierra del Fuego (Donoso and Donoso 2006; Thiers and Gerding 2007; Promis et al. 2009), the litter falls continuously throughout the year and the fruit contains three small seeds (3-4 mm length). However, both species are monoecious with solitary male flowers, but female flowers varies from only one solitary flower in $N$. pumilio appearing later at the distal extreme of shoots, to a group of three flowers in $N$. betuloides (Moore 1983; Rodríguez and Quezada 2003); for both species, budburst occurs during late spring (November), both are wind-pollinated species with high pollination efficiency and fruit development occurs during summer (Cuevas and Arroyo 1999; Donoso and Donoso 2006). After winter, the viable surviving nuts of Nothofagus species germinate in November-December during the same year of dispersion without a persisting seed bank in the forest floor. After germination, seedling can persist up to 25 years growing slowly in the forest floor (Cuevas and Arroyo 1999) in a shady understory. $N$. betuloides is a species best suited to shady environments (shade tolerant species) while $N$. pumilio shows a more positive response to canopy openings (medium shade tolerant species) (Donoso and Donoso 2006).

Previous studies describe that flowers, immature fruits and seeds of $N$. pumilio not only are exposed to predation of insect and birds (Martínez Pastur et al. 2008) but also could be consumed by rodents (Akodon, Euneomys and Oligoryzomys species) in the forest floor after dispersion. Meanwhile, there is no enough evidence about seed predation by rodents, birds or insects in $N$. betuloides forests.

\section{Study site characterization}

This study was developed on mature coetaneous Nothofagus forests ( $>250$ years) without harvesting impact on at least the last 50 years of south-west Tierra del Fuego, Argentina (Fig. 1). Three Nothofagus forest types were considered, according to their overstory composition: pure deciduous $N$. pumilio forests (Np), pure evergreen $N$. betuloides forests $(\mathrm{Nb})$ and mixed $N$. pumilio-N. betuloides forests $(\mathrm{M})$, with similar proportions of both species in overstory composition. Likewise, two geographical locations were selected where these three forest types could be found: coastal forest, close to the Beagle Channel within the Tierra del Fuego National Park where the altitude is $50-100$ m.a.s.l. and mountain forest, toward the inner island, located through Garibaldi Pass in last foothills of the Andes Mountain Range where the altitude is $300-350$ m.a.s.l. Each geographical location included two sampling sites combining pure and mixed forests (2 geographical locations $\times 2$ sites $\times 3$ forest types $=12$ ).

Climate in Tierra del Fuego Island is strongly influenced by oceanic current, Antarctica proximity and the insularity feature which determines a uniform climate regime with low range of annual temperature (7-10 ${ }^{\circ} \mathrm{C}$ of difference) (Burgos 1985). In the coast location selected for this study, mean annual temperature varies between 2.1 and $10.9{ }^{\circ} \mathrm{C}$ and accumulated rainfall is $710 \mathrm{~mm}$ year $^{-1}$ with abundant snow fall (Kreps et al. 2012), while in mountain location, mean annual temperature varies between -0.6 and $7.2{ }^{\circ} \mathrm{C}$ and accumulated rainfall is $545 \mathrm{~mm}$ year $^{-1}$ (Kreps et al. 2012).

\section{Forest structure}

To characterize and compare the canopy composition and forest structure of pure and mixed stands, we established 10 randomly located, independent plots for each forest type and geographical location $(N=3 \times 2 \times 10=60)$. We applied the angle count sampling method (Bitterlich 1984), using a Criterion RD-1000 (Laser Technology, USA) with a variable basal area factor (K) between 6 and 7; we measured the tree diameter at breast for each tree included in each plot, recording the species of each tree in the mixed stands. With this data, we calculated the basal area and tree density at the stand level. Additionally, dominant height was estimated on the three dominant trees in each plot using a clinometer and laser distance rangefinder (TruPulse 200, Laser Technology, USA). Above the centre of each plot, a hemispherical photograph was taken and analysed with Gap Light Analyzer v2.0 0 (Frazer et al. 2001) to calculate canopy cover as percentage, direct and diffuse radiation transmitted through canopy and total radiation ratio (ratio between total incident and transmitted radiation through canopy) during the growing season (September to April). For details of inputs and models, see Martínez Pastur et al. (2011). 


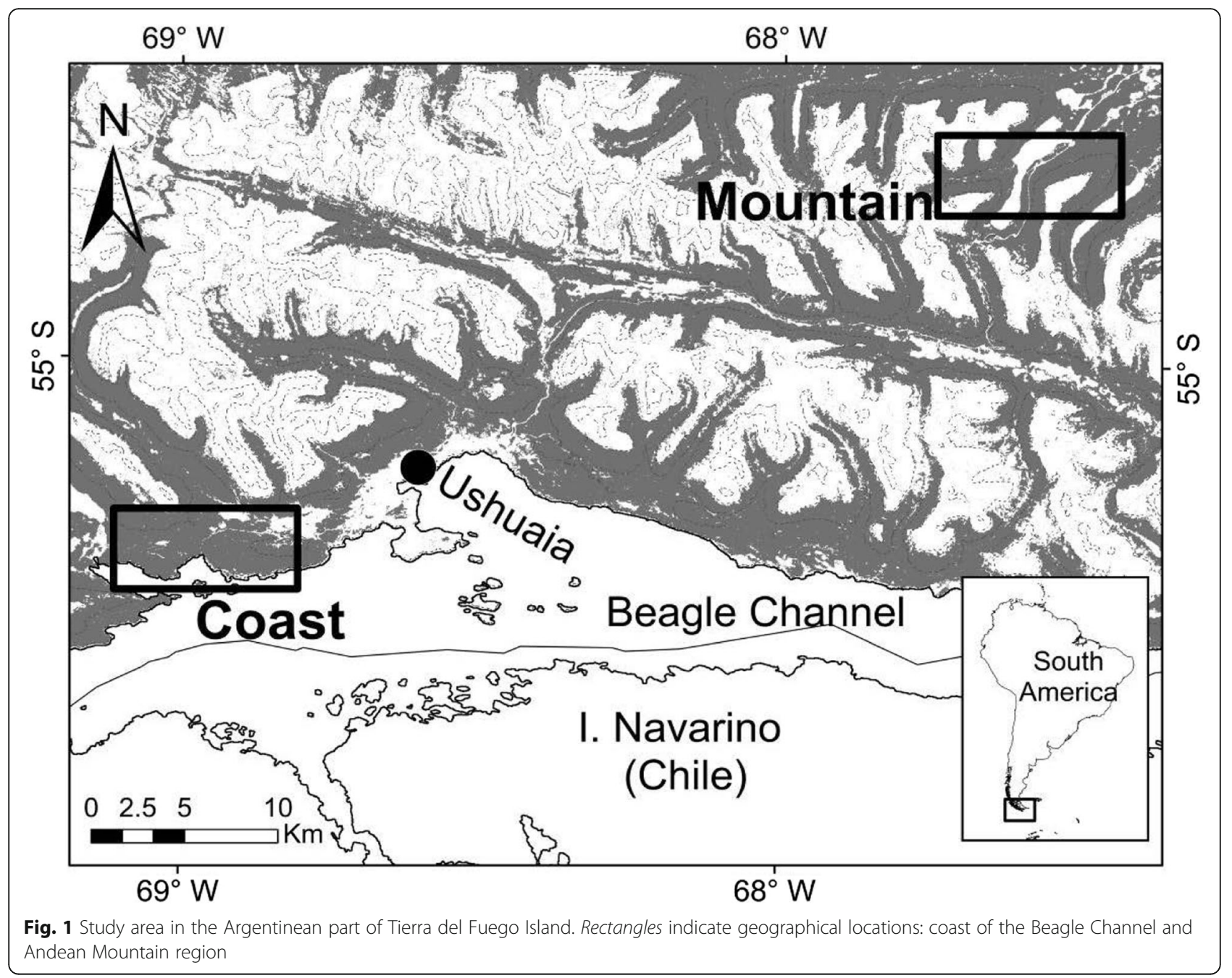

\section{Abscised biomass sampling}

Phenology was monthly monitored recording the fallen structures. For this, we used 20 randomly located, independent litter fall traps $\left(0.06 \mathrm{~m}^{2}\right.$ and $30 \mathrm{~cm}$ deep) for each forest type and geographical location $(N=3 \times 2 \times 20=120)$, which were perforated to allow rain and snow-water drainage. Litter fall was monthly collected (October 2012 to September 2013; except during winter, when pooled samples from June to September) and manually classified in reproductive (male and female flowers, immature fruits and seeds) and litter (leaves, fine branches less than $1-\mathrm{cm}$ diameter and miscellaneous components). We consider spontaneous abortions as premature female flowers and immature fruits fallen into the traps. Also, losses by predation were classified as fruits or mature seed predated by insect or predated by birds. Seeds without evident damage were considered sound seeds. Quality of such undamaged seeds was analysed through the manual opening of each seed, classifying them in empty or full seeds. Immediately, tetrazolium test (2,3,5triphenyltetrazolium chloride) was conducted over the full seeds to determine seed viability. For this, embryos were incubated for $24 \mathrm{~h}$ in a water dilution of $0.1 \%$ solution in darkness at $25{ }^{\circ} \mathrm{C}$ (Cuevas 2000) and then classified in viable seed or non-viable seeds according to the enzymatic activity. Reproductive and litter components were dried in an oven at $70{ }^{\circ} \mathrm{C}$ until constant weight and weighted with at precision of $\pm 0.0001 \mathrm{~g}$ to calculate biomass.

\section{Data and statistical analysis}

Reproductive and litter components were expressed as number per hectare $\left(\mathrm{N} \mathrm{ha}^{-1}\right)$ per year and/or biomass, expressed in tonne per hectare (ton $\mathrm{ha}^{-1}$ ) per year. The potential seed production (PSP) per trap was obtained by adding the quantity of female flowers, immature fruits and seeds, both predated or without evident damage. It can be considered a rough estimation of the total mature seeds that potentially would be produced if all female flowers were successfully pollinated 
(Yasaka et al. 2003). In the case of female flowers and immature fruits of $N$. betuloides, they were multiplied three times due to each female flower has a tricarpelar ovary bringing three seeds per fruit.

To evaluate how each reproductive component contributes to the PSP, we analysed those as proportions of the PSP per trap, which were expressed as percentage. To evaluate how premature flower abscission, fruit abortion and predation affected PSP, we also analysed those as proportions of the PSP per trap. Based on the biomass collected monthly, we build the phenological pattern of each forest type in coast and mountain sites.

We assessed the effect of overstory composition of each forest type and geographical location on forest structure: basal area $\left(\mathrm{m}^{2} \mathrm{ha}^{-1}\right)$, tree density $\left(\mathrm{n} \mathrm{ha}^{-1}\right)$, dominant height $(\mathrm{m})$, quadratic mean diameter $(\mathrm{cm})$, canopy cover $(\%)$, direct radiation $\left(\mathrm{W} \mathrm{m}^{2}\right)$, diffuse radiation $\left(\mathrm{W} \mathrm{m}^{2}\right.$ ) and total radiation ratio (\%) and reproductive variables (male and female flowers, immature fruits without damage, predated by insects and predated by birds, seeds without damage, predated by insects and predated by birds, potential seed production, empty seeds, viable seeds and non-viable seeds, for total quantities and proportions related to potential seed production) using two-way ANOVAs at $p=0.05$. Main factors of these analysis were forest type (three levels: deciduous, evergreen and mixed) and geographical location with two levels: coast and mountain. Variables were lntransformed before the analyses to accomplish statistical ANOVA assumptions, but not transformed average data are shown in Tables. We also used the post hoc Tukey honestly significant difference test $(p<0.05)$ to describe differences of mean values. To compare the quantity of reproductive structures from $\mathrm{Np}$ and $\mathrm{Nb}$ in mixed forests, we applied non-parametrical Kruskal-Wallis test $(p=0.05)$, separately for each geographical location.

\section{Results}

\section{Forest structure}

Forest structure showed significant differences among forest types and geographical locations, but interactions existed for basal area and direct radiation (Table 1). Np forests had significantly lower tree density but greater mean diameter and dominant height than $\mathrm{Nb}$ forests. $\mathrm{M}$ forests did not differ from $\mathrm{Nb}$ forests in density and dominant height, but mean diameter $\mathrm{M}$ showed an intermediate situation between $\mathrm{Np}$ and $\mathrm{Nb}$ forests. Canopy cover was significantly higher in mountain than in coast, while differences were not significant between geographical locations for the other variables, except basal area. Forest types $\times$ location interactions in basal area occurred due to $\mathrm{Np}$ forests had significant lower values than $\mathrm{M}$ and $\mathrm{Nb}$ in mountain sites but did not in coast. For direct radiation, interactions occurred due to significant differences among forest types in the coast: the interior of $\mathrm{M}$ stands received significantly higher direct radiation than $\mathrm{Np}$ and $\mathrm{Nb}$ stands but did not in mountain. And simultaneously, significant differences between geographical locations occurred only in $\mathrm{Np}$ stands, with greater direct radiation in the mountains than in the coast.

\section{Flowering and seeding patterns, premature abscission and predation}

Most of the considered variables at the flowering and seeding stage were related to forest type and geographical location (Table 2), but we detected significant interactions in some variables. Male flower production differed among forest types for each geographical location, being greater in $\mathrm{Np}$ than in $\mathrm{Nb}$ stands in the coast (with intermediate values for mixed stands). But in mountains, it was highest in $\mathrm{M}$ and lowest in $\mathrm{Np}$ and $\mathrm{Nb}$ stands. Likewise, male flower production was similar

Table 1 Effect of forest type ( $N p$ deciduous Nothofagus pumilio, Nb evergreen N. betuloides, M mixed forests) and geographical location (coast, mountain) on forest structure variables: basal area $(B A)\left(m^{2}\right.$ ha $\left.{ }^{-1}\right)$, tree density $(N)\left(n h^{-1}\right)$, dominant height $(D H)(m)$, quadratic mean diameter (MD) ( $\mathrm{cm})$, canopy cover (CC) (\%), direct radiation (DR) $\left(\mathrm{W} \mathrm{m}^{2}\right)$, diffuse radiation (DF) $\left(\mathrm{W} \mathrm{m}^{2}\right)$ and total radiation ratio (TR) (\%). N was $\operatorname{In}(Y)$ transformed to accomplish ANOVA assumptions, but not transformed data are shown

\begin{tabular}{|c|c|c|c|c|c|c|c|c|c|}
\hline Factor & & BA & $N$ & $\mathrm{DH}$ & $\mathrm{MD}$ & CC & $\mathrm{DR}$ & DF & TR \\
\hline \multirow[t]{4}{*}{ A: Forest type } & $\mathrm{Np}$ & $66.55 a$ & $380.68 a$ & $21.97 \mathrm{~b}$ & $63.19 c$ & 89.98 & 0.80a & 3.36 & 12.58 \\
\hline & M & 77.10ab & $909.87 b$ & $17.65 a$ & $47.98 \mathrm{~b}$ & 88.32 & $1.02 \mathrm{a}$ & 4.27 & 15.97 \\
\hline & $\mathrm{Nb}$ & $84.50 \mathrm{~b}$ & $1238.47 b$ & $15.93 a$ & $37.54 a$ & 87.02 & $0.78 a$ & 3.93 & 14.20 \\
\hline & $F(p)$ & $7.12(0.002)$ & $21.36(<0.001)$ & $12.31(<0.001)$ & $33.35(<0.001)$ & $2.55(0.088)$ & $3.24(0.047)$ & $2.99(0.059)$ & $3.03(0.057)$ \\
\hline \multirow[t]{3}{*}{ B: Location } & Coast & $71.37 a$ & 790.02 & 18.73 & 51.73 & $87.37 a$ & 0.87 & 4.08 & 14.97 \\
\hline & Mountain & $80.73 b$ & 895.97 & 18.31 & 47.41 & $89.52 b$ & 0.86 & 3.62 & 13.52 \\
\hline & $F(p)$ & $5.76(0.020)$ & $0.15(0.701)$ & $0.17(0.683)$ & $2.81(0.100)$ & $4.03(0.049)$ & $0.02(0.884)$ & $2.27(0.138)$ & $1.67(0.202)$ \\
\hline$A \times B$ & $F(p)$ & $5.71(0.006)$ & $2.61(0.083)$ & $1.80(0.175)$ & $0.75(0.476)$ & $1.73(0.187)$ & $3.71(0.031)$ & $0.76(0.471)$ & $1.22(0.303)$ \\
\hline
\end{tabular}

Different letters in each row showed differences by Tukey test at $p<0.05$

$F$ Fisher's test at $p<0.05$ 
Table 2 Effect of forest types (Np deciduous Nothofagus pumilio, Nb evergreen N. betuloides, M mixed forests) and geographical location (coast, mountain) on quantity ( $\times 100$ thousand ha ${ }^{-1}$ ) of male (MF) and female (FF) flowers, immature fruits (without damage - IF, predated by insects - IFI and predated by birds - IFB), seeds (without damage — S, predated by insects — SI and predated by birds - SB) and potential seed production (PSP)

\begin{tabular}{lllllllllll}
\hline Factor & & MF & FF & IF & IFI & IFB & S & SI & SB & PSP \\
\hline A: Forest type & $\mathrm{Np}$ & $27.0 \mathrm{~b}$ & $1.5 \mathrm{~b}$ & $1.6 \mathrm{ab}$ & 0.4 & 0.1 & $5.2 \mathrm{a}$ & $0.6 \mathrm{a}$ & 0.3 & $9.2 \mathrm{a}$ \\
& $\mathrm{M}$ & $27.1 \mathrm{~b}$ & $2.2 \mathrm{~b}$ & $1.8 \mathrm{~b}$ & 0.5 & 0.2 & $19.3 \mathrm{~b}$ & $1.7 \mathrm{~b}$ & 0.6 & $27.3 \mathrm{~b}$ \\
& $\mathrm{Nb}$ & $10.9 \mathrm{a}$ & $0.2 \mathrm{a}$ & $0.5 \mathrm{a}$ & 0.1 & 0.1 & $24.1 \mathrm{~b}$ & $0.8 \mathrm{ab}$ & 0.3 & $26.2 \mathrm{~b}$ \\
& $\mathrm{~F}$ & 10.14 & 6.22 & 2.35 & 2.16 & 0.22 & 14.93 & 3.83 & 1.70 & 12.47 \\
& $(p)$ & $(<0.001)$ & $(0.003)$ & $(0.100)$ & $(0.120)$ & $(0.803)$ & $(<0.001)$ & $(0.025)$ & $(0.188)$ & $(<0.001)$ \\
& Coast & 24.3 & 1.7 & $1.3 \mathrm{~b}$ & $0.6 \mathrm{~b}$ & 0.1 & 18.7 & $1.4 \mathrm{~b}$ & 0.4 & $23.0 \mathrm{~b}$ \\
B: Location & Mountain & 19.0 & 0.9 & $0.3 \mathrm{a}$ & $0.1 \mathrm{a}$ & 0.2 & 13.6 & $0.6 \mathrm{a}$ & 0.4 & $17.8 \mathrm{a}$ \\
& $\mathrm{F}$ & 2.40 & 2.98 & 7.98 & 9.82 & 2.01 & 2.99 & 5.55 & 0.03 & 5.19 \\
& $(p)$ & $(0.124)$ & $(0.087)$ & $(0.006)$ & $(0.002)$ & $(0.159)$ & $(0.086)$ & $(0.020)$ & $(0.871)$ & $(0.025)$ \\
& $F$ & 6.26 & 1.52 & 1.57 & 2.47 & 0.41 & 16.09 & 7.01 & 1.70 & 7.86 \\
$\mathrm{~A} \times \mathrm{B}$ & $(p)$ & $(0.003)$ & $(0.223)$ & $(0.212)$ & $(0.089)$ & $(0.666)$ & $(<0.001)$ & $(0.001)$ & $(0.188)$ & $(<0.001)$ \\
& & & & & & & & & &
\end{tabular}

Different letters in each row showed differences by Tukey test at $p<0.05$

$F$ Fisher's test at $p<0.05$

between geographical locations for each forest type, except for Np forests, which showed higher quantity of male flowers in coast than in mountain.

Premature abscised female flowers and immature fruits occurred twice in $\mathrm{Np}$ and $\mathrm{M}$ than in $\mathrm{Nb}$ forests (Table 2). Losses by abscised female flowers were similar between geographical locations, but aborted fruits were significantly greater in the coast than in the mountain. Seed production was related to forest type but not to the geographical location (Table 3 ). However, it could be due to forest type $\times$ location interactions: at coastal sites, $\mathrm{Nb}$ produced higher number of seeds than the other stands, while in mountain sites, $M$ showed the highest values and $\mathrm{Np}$ stands did not evidence differences between geographical locations. The incidence of seed predation varied according to the animal predator, because insect predation was related to forest type and geographical location while bird predation was not (Table 2). However, forest type $\times$ location interactions occurred for insect predation due to $M$ stands had higher values than $\mathrm{Np}$ and $\mathrm{Nb}$ stands in coastal sites, while $\mathrm{Nb}$ stands had greatest values than $\mathrm{M}$ and $\mathrm{Np}$ stands in mountains. Likewise, it was highest in coast for $\mathrm{Np}$ and $\mathrm{M}$ forests, but $\mathrm{Nb}$ forests showed an inverse pattern. Finally,

Table 3 Effect of forest types (Np deciduous Nothofagus pumilio, Nb evergreen N. betuloides, M mixed forests) and geographical location (coast, mountain) on proportions related to potential seed production (\%) of female flowers (FF), immature fruits (without damage — IF, predated by insects — IFI, predated by birds - IFB) and seeds (without damage — S, predated by insects—SI and predated by birds-SB)

\begin{tabular}{|c|c|c|c|c|c|c|c|c|}
\hline Factor & & $\mathrm{FF} \%$ & $\mathrm{IF} \%$ & $\mathrm{IFI} \%$ & IFB\% & $\mathrm{S} \%$ & $\mathrm{SI} \%$ & SB\% \\
\hline \multirow[t]{5}{*}{ A: Forest type } & $\mathrm{Np}$ & $19.6 b$ & $10.6 b$ & 3.2 & 1.2 & $59.6 a$ & 3.0 & 2.0 \\
\hline & M & $7.2 \mathrm{a}$ & $5.4 a b$ & 1.5 & 0.3 & $79.6 b$ & 4.4 & 1.6 \\
\hline & $\mathrm{Nb}$ & $2.2 \mathrm{a}$ & $0.6 a$ & 0.6 & 0.5 & $90.0 \mathrm{~b}$ & 5.2 & 0.9 \\
\hline & $F$ & 9.35 & 5.25 & 1.64 & 1.50 & 18.00 & 1.01 & 0.98 \\
\hline & $(p)$ & $(<0.001)$ & $(0.007)$ & $(0.198)$ & $(0.227)$ & $(<0.001)$ & $(0.369)$ & $(0.378)$ \\
\hline \multirow[t]{4}{*}{ B: Location } & Coast & 9.3 & 6.8 & $2.9 \mathrm{~b}$ & 0.1 & 75.1 & 4.7 & 1.0 \\
\hline & Mountain & 9.2 & 3.8 & $0.4 a$ & 1.7 & 79.3 & 3.7 & 1.9 \\
\hline & $F$ & 0.05 & 1.30 & 6.74 & 3.57 & 0.56 & 0.82 & 1.92 \\
\hline & $(p)$ & $(0.821)$ & $(0.258)$ & $(0.012)$ & $(0.061)$ & $(0.454)$ & $(0.368)$ & $(0.168)$ \\
\hline \multirow[t]{2}{*}{$A \times B$} & $F$ & 0.24 & 0.47 & 2.53 & 1.15 & 2.91 & 7.82 & 2.23 \\
\hline & $(p)$ & $(0.7850)$ & $(0.624)$ & $(0.085)$ & $(0.320)$ & $(0.059)$ & $(<0.001)$ & $(0.112)$ \\
\hline
\end{tabular}

Different letters in each row showed differences by Tukey test at $p<0.05$

$F$ Fisher's test at $p<0.05$ 
different forest type produced significant different potential seed production (Table 2). Also, potential seed production for $\mathrm{Nb}$ forests was greater in coast than in mountain, while differences were not found between geographical locations for $\mathrm{M}$ and $\mathrm{Np}$ forests.

We observed that successful undamaged seeds represented the major proportion of potential seed production compared to flowers and immature fruits. On the other hand, predated seeds and fruits accounted as the lowest proportion of the potential seed production (Table 3).

Table 3 shows the proportional contribution of female flowers, immature (undamaged) fruits and predated structures to potential seed production. These variables were similar between geographical locations, except the proportions of immature fruits predated by insects. As was expected, seeding effectiveness (proportion of undamaged seeds) was significantly higher in $\mathrm{Nb}$ and $\mathrm{M}$ forests compared to $\mathrm{Np}$ forests, but such differences were not found between geographical locations. Interactions were only detected for seeds predated by insects due to $\mathrm{M}$ forests presented higher values than $\mathrm{Nb}$ forests in coast, but $\mathrm{Nb}$ forests was greatest in mountains, without differences among $\mathrm{M}$ and $\mathrm{Np}$ stands.

The relation between reproductive structures from $\mathrm{Np}$ and $\mathrm{Nb}$ in mixed forests showed significant differences for undamaged seeds and potential seed production at both coast and mountain and in seeds predated by insects at mountain (Fig. 2). The other variables did not present significant differences between species at each geographical location, but marginal differences were observed for male flowers at mountain and female flower at coast. Undamaged seeds and potential seed production for $\mathrm{Nb}$ were significantly more abundant than those for $\mathrm{Np}$ in mixed forests at both coast and mountain, while seeds predated by birds from $\mathrm{Nb}$ were significantly more abundant than those from $\mathrm{Np}$ at mountain. However, insect predation was greater in $\mathrm{Np}$ than in $\mathrm{Nb}$ fruits and seeds at coast, while it occurred only in $\mathrm{Nb}$ fruits and seeds at mountain. Immature fruits predation by birds was not observed in coast for both species, neither in $\mathrm{Nb}$ at mountain. Meanwhile, seed predation by birds was greater for $\mathrm{Nb}$ at coast but followed an inverse pattern at mountain.

\section{Seed quality}

Seed quality was related to forest type and geographical location (Table 4), but interactions occurred. At coast, empty, viable and non-viable seeds were higher in $\mathrm{Nb}$ forests, with similar and lower values in $\mathrm{M}$ and $\mathrm{Np}$ forests. At mountain, $M$ forests presented greater values for the three same variables, presenting lower and similar values in $\mathrm{Nb}$ and $\mathrm{Np}$ forests. On the other hand, $\mathrm{Np}$ had more empty, viable and non-viable seeds at coast than at mountain; Np had similar values for empty and viable seeds in both geographical locations, but mountain showed more non-viable seeds than coast; and M forest had slightly greater values of empty and viable seeds in mountain than in coast, difference that was highlighted for non-viable seeds.

The proportions related to potential seed production of empty and viable seeds were also greater for $\mathrm{Nb}$ forest than for $\mathrm{M}$ and $\mathrm{Np}$ forests in coast. At mountain, proportion of empty seeds was lower in $\mathrm{Np}$ forests, compared to $\mathrm{Nb}$ and $\mathrm{M}$ forests (with higher and similar values), while there were no differences among forest types for viable seeds at this geographical location. Finally, the proportion of viable seed was also similar between geographical locations for the three forest types. The relation between seed quality from $\mathrm{Np}$ and $\mathrm{Nb}$ in mixed forests showed significant differences for empty seeds at both coast and mountain, and marginal differences for viable seeds in coast, with greater values for $\mathrm{Nb}$ in the three situations (Fig. 2).

\section{Reproductive phenology of pure and mixed stands based on biomass production}

Reproductive phenological patterns of pure and mixed stands presented differences related to geographical locations (Fig. 3), with early beginning of flowering in coast during early spring (October). Also, coast showed a pattern of biomass falling more distributed over the months, while in mountain, the occurrence of each reproductive event was more concentrated. However, the main reproductive phenological differences were related to the leaf habit of each tree species.

Female flowers occurred earlier in Np stands (maximum of $47 \%$ in November and $73 \%$ in December for coast and mountain, respectively) than in $\mathrm{Nb}$ stands (100\% in December and 96\% in January, for coast and mountain, respectively). Male flower occurs all yearround especially in $\mathrm{Np}$ forest, showing the greater occurrence during October in the coast (84\%) and during November in the mountain (92\%). Fruiting occurred at the same time in all forest types, as premature falls were only recorded during January and February, except for some minor events at the coastal sites. Seed fall occurred from March to winter months in all forest types and in both coast and mountain. Seeds of Np species showed a maximum biomass production concentrated on April ( $45 \%$ in coast and $67 \%$ in mountain) while seeds of $\mathrm{Nb}$ species fallen more distributed among March $(18 \%$ in coast and 14\% in mountain), April (24 and 25\%, respectively) and May (40 and 40\%, respectively). Finally, litter fall occurred all year-round, but in Np forests, it peaked during April (57\% in coast and 67\% in mountain) at the same time that seed fall, while in $\mathrm{Nb}$ forests, litter fall was more evenly distributed. Litter biomass collected at 


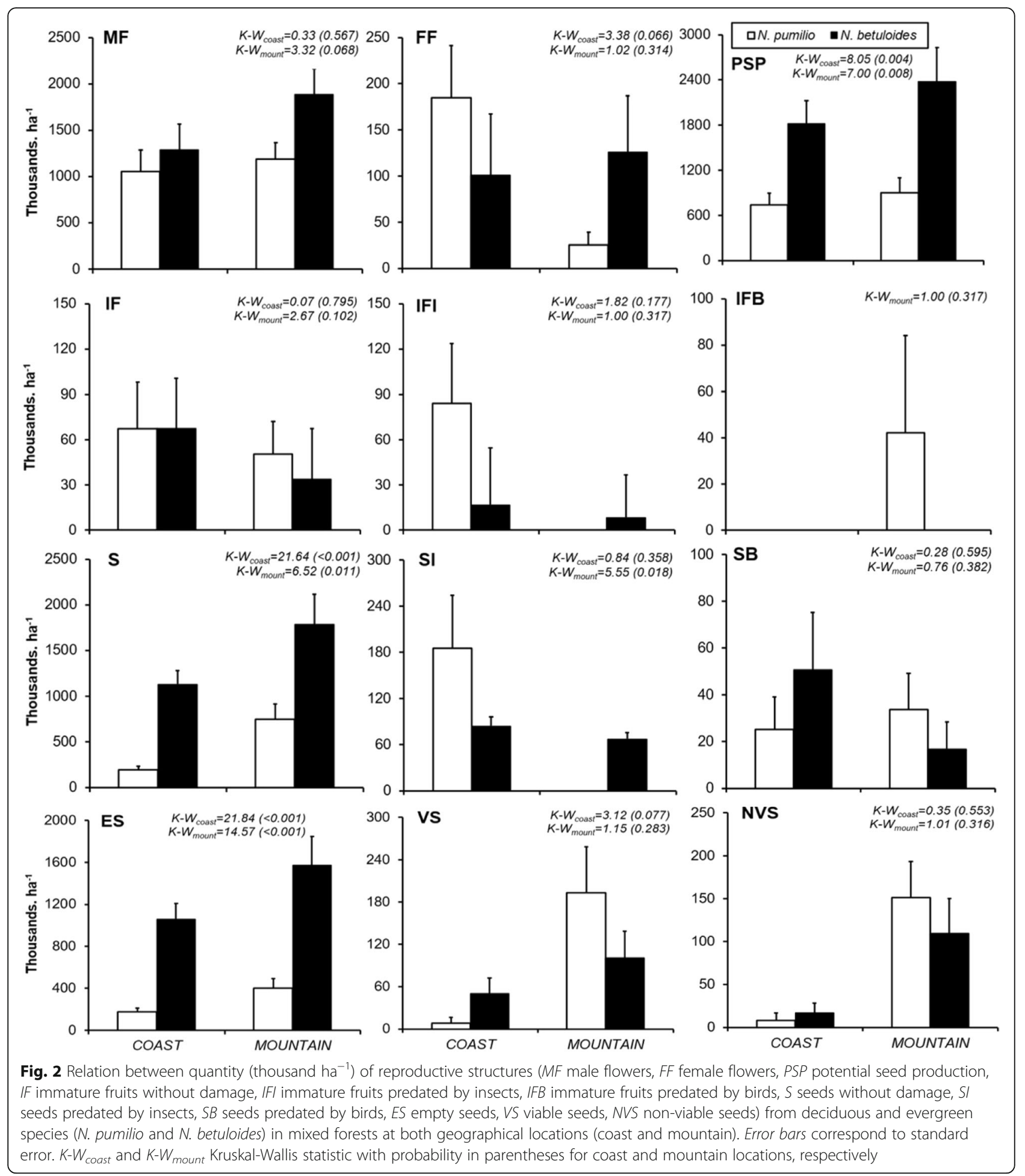

coast reached $3.93 \pm 0.23$ ton $\mathrm{ha}^{-1}$ per year (mean \pm SD) in $\mathrm{Np}$ forest, $2.70 \pm 0.75$ ton $\mathrm{ha}^{-1}$ in $\mathrm{M}$ and $1.78 \pm$ 0.48 ton $\mathrm{ha}^{-1}$ in $\mathrm{Nb}$ forests. Litter biomass collected at mountain reached $2.78 \pm 0.27$ ton $\mathrm{ha}^{-1}$ in $\mathrm{Np}$ forest, $2.36 \pm 0.53$ ton $\mathrm{ha}^{-1}$ in $\mathrm{M}$ and $1.89 \pm 0.28$ ton $\mathrm{ha}^{-1}$ in $\mathrm{Nb}$ forests.

\section{Discussion}

Reproductive phenological patterns in pure forests compared to mixed forests

In this study, we assessed the reproductive phenology and success of pure (deciduous or evergreen) and mixed Nothofagus species stands in sub-Antarctic forests. A 
Table 4 Effect of forest types ( $N p$ deciduous Nothofagus pumilio, Nb evergreen N. betuloides, M mixed forests) and geographical location (coast, mountain) on empty seeds (ES), viable seeds (VS) and non-viable seeds (NVS), both in quantity ( $\times 100$ thousand ha ${ }^{-1}$ ) and proportions related to potential seed production (\%)

\begin{tabular}{|c|c|c|c|c|c|c|c|}
\hline Factor & & ES & $\mathrm{ES} \%$ & VS & VS\% & NVS & NVS\% \\
\hline \multirow[t]{5}{*}{ A: Forest type } & $\mathrm{Np}$ & $3.74 a$ & $32.2 \mathrm{a}$ & $0.2 \mathrm{a}$ & 1.3 & 1.0 & $8.8 b$ \\
\hline & M & $16.1 b$ & $62.3 b$ & $0.8 \mathrm{ab}$ & 1.8 & 1.4 & $3.9 a$ \\
\hline & $\mathrm{Nb}$ & $21.4 b$ & $76.1 \mathrm{C}$ & $1.3 b$ & 2.8 & 1.8 & $4.2 \mathrm{a}$ \\
\hline & $F$ & 18.48 & 33.98 & 5.06 & 1.31 & 1.38 & 3.53 \\
\hline & $(p)$ & $(<0.001)$ & $(<0.001)$ & $(0.008)$ & $(0.274)$ & $(0.256)$ & $(0.032)$ \\
\hline \multirow[t]{4}{*}{ B: Location } & Coast & $16.6 b$ & $61.9 b$ & 0.9 & 1.9 & 1.2 & $2.9 a$ \\
\hline & Mountain & $10.6 a$ & $51.9 a$ & 0.5 & 2.1 & 1.6 & $8.3 b$ \\
\hline & F & 6.24 & 5.05 & 1.95 & 0.06 & 1.46 & 10.01 \\
\hline & $(p)$ & $(0.014)$ & $(0.0266)$ & $(0.165)$ & $(0.802)$ & $(0.230)$ & $(0.002)$ \\
\hline \multirow[t]{2}{*}{$A \times B$} & $F$ & 14.33 & 3.57 & 8.41 & 3.82 & 13.32 & 8.89 \\
\hline & $(p)$ & $(<0.001)$ & $(0.031)$ & $(<0.001)$ & $(0.023)$ & $(<0.001)$ & $(<0.001)$ \\
\hline
\end{tabular}

Different letters in each row showed differences by Tukey test at $p<0.05$

$F$ Fisher's test at $p<0.05$

greater sexual reproductive success of deciduous compared with the evergreen species, or vice versa, within mixed stands may contribute significantly to shift entire community composition. According to our results, mixed forest reflected an intermediate situation between pure N. pumilio and $N$. betuloides for all reproductive variables. The flowering period was similar between $N$. pumilio and mixed forests, while seeding period was similar between $N$. betuloides and mixed. Currently, there are scarce previous descriptions that could help us to understand the influence of each Nothofagus species on mixed stands. However, our findings (i.e. relation between reproductive structures of $N$. pumilio and $N$. betuloides species in mixed forests) highlight a major influence of the $N$. betuloides species (and its characteristics) on the seeding patterns occurring in mixed stands. The high tree density in $N$. betuloides forest, which resembles density of mixed forest, could be determining of the high potential seed production, as has been documented for other Nothofagus species (Martínez Pastur et al. 2008; Soler et al. 2010).

Recent studies suggest that mixtures where species differ in shade tolerance and leaf phenology are more productive than pure or monospecific stands ( $\mathrm{Lu}$ et al. 2016), which enhance ecosystem functioning (i.e. reproductive cycle). In mixed forests, we found some advantages in reproductive performance for both deciduous and evergreen species compared to pure forests. At canopy level, the evergreen species in mixed forests has greater availability of light during one part of the year, which does not happen in pure evergreen forests. According to Pretzsch (2014), the multiple crown overlaps in mixed forest to maximize the space filling, drawing additional advantages in resource utilization. In our study, the greatest number of male flowers of $N$. betuloides in mixed forest compared to pure evergreen could be related to higher solar radiation at the canopy level. Such crown overlapping might also offer more protection (i.e. against frost, strong rains) to reproductive structures of deciduous species contrary to what happened in pure deciduous forests. In fact, our data show that $N$. betuloides and mixed forests were the most efficient stands in terms of success flowering as the total percentage of aborted structures (flowers + fruits) were less than $15 \%$, contrary to $N$. pumilio pure forests where abortion reduces by almost $30 \%$ the PSP due to failures during flowering.

Higher number of seed produced in mixed and $N$. betuloides forests is likely related to the number of seeds per fruit, as $N$. betuloides had three seeds per nut. Moreover, $N$. betuloides forest also reflects the high percentage of seeds in relation to PSP demonstrating a better performance in seed production than $N$. pumilio and mixed forests. There is consistent evidence that smallerseeded species produce more seeds per unit than largerseeded species (Leishman et al. 2000), as we recorded for $N$. betuloides and N. pumilio, respectively. However, from the seedling establishment point of view, seed mass (i.e. reserves accumulation) best reflects the resources available for seedling (Leishman et al. 2000). Then, larger and better-provisioned offspring, like $N$. pumilio in our case, have a greater chance of successful establishment. Our analysis of seed quality confirms this idea, as empty and non-viable seeds reduce significantly the potential of reproduction, and it was noticeable in $N$. betuloides and mixed forests. However, there were again clear advantages of mixed forests compared to pure forests as both 


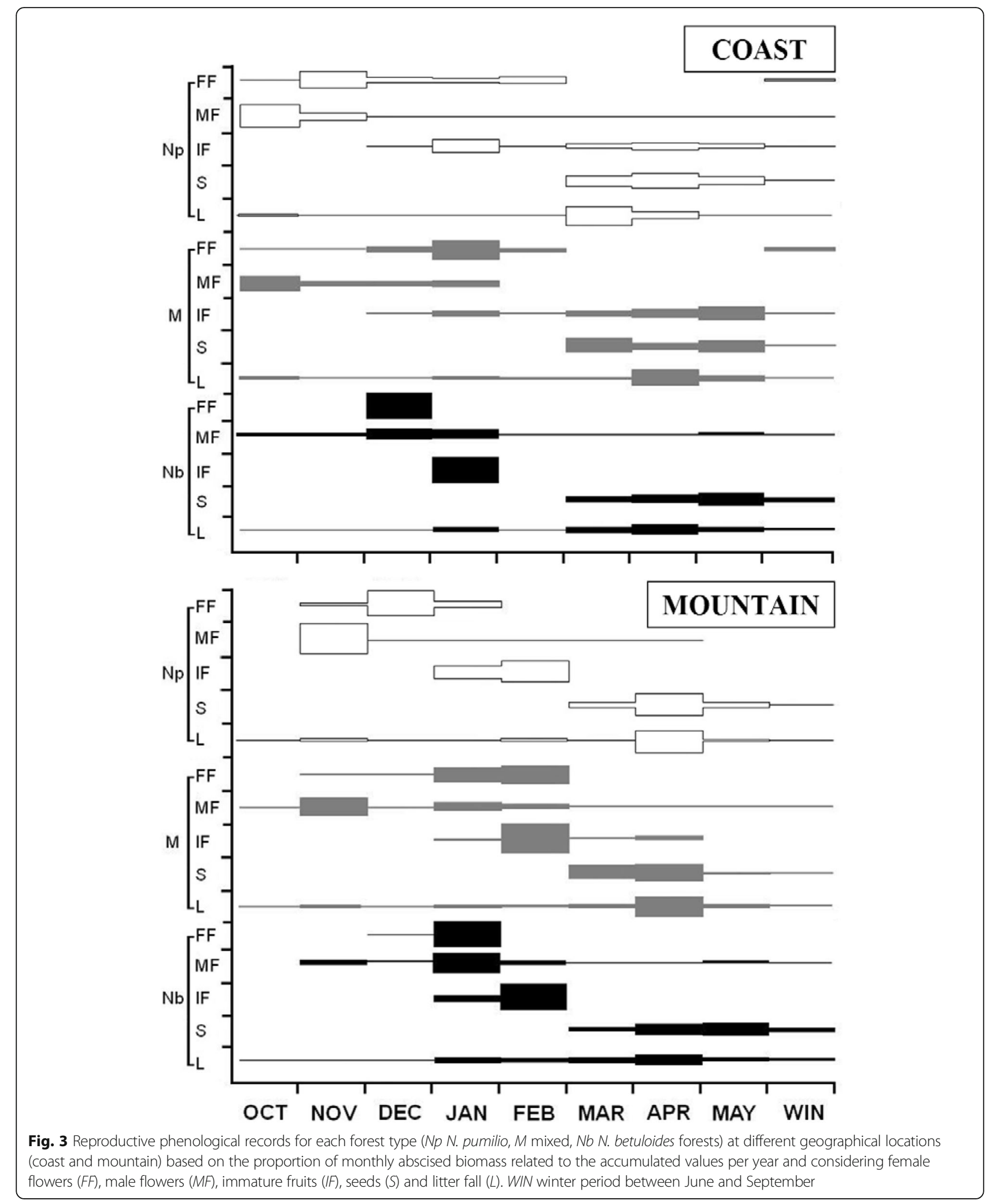

species showed lower number of empty seeds in mixtures than in their respective pure forests. This might be other evidence of temporal and spatial resource use complementary (Pretzsch 2014) which allow the coexistence of tree species that differ in structural and functional traits. 
Different seed size also offer differential opportunities for predators (Leishman et al. 2000; Espelta et al. 2009), and thus, we would expect high predation rate in $N$. pumilio (larger-seeded species) than in $N$. betuloides forests (smaller-seeded species). However, in our study, these losses were negligible (7-9\%) for the entire reproductive cycle and did not differ among the forest types. Since seed predation usually is regulated by inter-annual variability in seed production (Kelly et al. 2002; Yasaka et al. 2003; Espelta et al. 2009), it is necessary to increase the timeline to assess the medium or long-term incidence of seed predation on the reproductive output of deciduous-evergreen mixed Nothofagus forests.

\section{Reproductive phenology in coastal and mountain sites}

Growing season at these latitudes is restrained to the summer months (Massaccesi et al. 2008), and regional climate determined its duration. Also, climate events that occurred during the long winter season influence over summer season, influencing the ecological conditions inside forests, e.g. higher snow accumulation during winter enlarge ice melting period, increasing the amount of water available in the forest floor during the summer season (Bales et al. 2011). Specifically, the thermal and rainfall gradients between the coast and mountain locations (e.g. low-high thermal amplitude, low-high precipitation gradient) affect the reproductive phenology of trees (Frangi et al. 2005), i.e. seasonally recurrent activity, such as the timing of plant flowering. Our results support this idea, as we detected a strong effect of geographical location on seed production as well as on the loss factors during flowering and seeding stages. However, the deciduous $N$. pumilio was less responsive to geographical locations, while the marine climate seems to be more favourable for the evergreen $N$. betuloides. This could be related to habitat requirements (temperature, air humidity) of each tree species, as $N$. betuloides inhabits more humid and rainy areas than $N$. pumilio. Not only Torres et al. (2015) demonstrated the relevance of rainfall on Nothofagus seed production in Tierra del Fuego Island but also Richardson et al. (2005) found that cold and humid summers produce a higher number of fruits in Nothofagus solandri forests of New Zealand. Kon et al. (2005) found correlations between minimum temperatures of the previous spring and seed production of Fagus crenata forests.

Our results have implications for interpreting the role of regional climate on reproductive phenology and the potential impacts of climate change at landscape and community levels of ecological organization. In Southern Patagonia, the maximum temperature and annual precipitation are predicted to increase until the end of the twenty-first century, possibly leading to a higher net primary productivity (Kreps et al. 2012). Forest tree species might have different sensitivities towards changing climate conditions, based on their specific ecophysiological thresholds and traits. Because our data correspond to only one growing season, it is not possible to interpret clearly the reproductive response of each tree species and therefore the coexistence of both deciduous and evergreen in mixed forests or the predominance of one species over the other. This study offers a significant first approach to the study of reproductive phenology in mixed forests, but more years of study (including mast years) are needed.

\section{Conclusions}

We assessed the role of reproductive phenology and reproductive success in the dynamic of mixed forests, to evaluate whether there is stability of the mixed structure or replacement of one species by another. Our results show that both deciduous and evergreen species have reproductive advantages in mixed compared to pure forests, indicating the coexistence of tree species that differ in structural and functional traits. However, pure evergreen and mixed forests have more similarities in their reproductive traits and the incidence of the limiting factors, demonstrating a greater influence of evergreen species compared to deciduous species in the mixed forests. Because of the short duration of this study and the unclear influence of geographical location, we cannot affirm whether mixed forests are stable communities or one of the tree species reproduces more successfully.

\section{Abbreviations \\ BA: Basal area $\left(\mathrm{m}^{2} \mathrm{ha}^{-1}\right)$; CC: Canopy cover (\%); DF: Diffuse radiation $\left(\mathrm{W} \mathrm{m}^{2}\right)$; $\mathrm{DH}$ : Dominant height (m); DR: Direct radiation $\left(\mathrm{W} \mathrm{m}^{2}\right)$; ES: Empty seeds; FF: Female flowers; IF: Immature fruits; IFB: Immature fruits predated by birds; IFI: Immature fruits predated by insects; M: Mixed forests; MD: Quadratic mean diameter (cm); MF: Male flowers; N: Tree density $\left(\mathrm{n} \mathrm{ha}{ }^{-1}\right.$ ); \\ Nb: Nothofagus betuloides; Np: Nothofagus pumilio; NVS: Non-viable seeds; PSP: Potential seed production; S: Seeds; SB: Seeds predated by birds; SI: Seeds predated by insects; TR: Total radiation ratio (\%); VS: Viable seeds; WIN: Winter period between June and September}

\section{Acknowledgements}

The authors gratefully thank the Centro Austral de Investigaciones Científicas (CADIC, CONICET) and Tierra del Fuego National Park (PNTDF) for their support during the realization of this work.

\section{Authors' contributions}

MTM designed the study, conducted the sample collection and laboratory analysis and wrote the manuscript. LM conducted the sample collection and laboratory analysis. MVL revised the manuscript draft and provided the statistical assistance. AP studied and revised the manuscript drafts. GMP generated the idea, designed this study and revised the manuscript draft. RS designed the study, provided the statistical assistance and wrote and revised the manuscript drafts. All authors read and approved the final manuscript.

\section{Competing interests}

The authors declare that they have no competing interests.

\section{Author details}

${ }^{1}$ National Scientific and Technical Research Council (CONICET), Austral Center for Scientific Research (CADIC-CONICET), Houssay 200, 9410 Ushuaia, Tierra 
del Fuego, Argentina. ${ }^{2}$ Department of Silviculture and Nature Conservation, University of Chile, Av. Santa Rosa 11315, 9206 Santiago, La Pintana, Chile.

\section{Received: 29 June 2016 Accepted: 19 November 2016 Published online: 07 December 2016}

\section{References}

Bahamonde HA, Peri PL, Monelos LH, Martínez Pastur G (2011) Ecological aspects of regeneration from seeds of Nothofagus antarctica native forest in Southern Patagonia, Argentina. Bosque 32:20-29

Bales RC, Hopmans JW, O'Geen A, Meadows M, Hartsough P, Kirchner P, Hunsaker C, Beaudette D (2011) Soil moisture response to snowmelt and rainfall in a Sierra Nevada mixed-conifer forest. Vadose Zone J 10:786-799

Bergeron Y, Chen HYH, Kenkel NC, Leduc AL, Macdonald SE (2014) Boreal mixedwood stands dynamics: ecological processes underlying multiple pathways. For Chron 90(2):202-213

Bitterlich W (1984) The relascope idea. Relative measurements in forestry. Commonw Agr Bureaux, London, UK, p 242

Burgos J (1985) Clima del extremo austral de Sudamérica. In: Boelcke O, Moore DM, Roig FA (eds) Dreiss Transecta Botánica de la Patagonia Austral. CONICET (Argentina), Royal Society (Great Britain) and Instituto de la Patagonia, Chile, pp 10-48

Choquenot D, Ruscoe WA (2000) Mouse population eruptions in New Zealand forests: the role of population density and seedfall. J Anim Ecol 69:1058-1070

Chuine I (2010) Why does phenology drive species distribution? Phil Trans R Soc B 365:3149-3160

Cleland EE, Chuine I, Menzel A, Mooney HA, Schwartz MD (2007) Shifting plant phenology in response to global change. Trends Ecol Evol 22(7):357-365

Cruz G, Caprile R, Promis A, Cabello G (2007) Structural and biometric characterization of Nothofagus betuloides production forests in the Magellan Region, Chile. J Sustainable For 24:123-140

Cuevas JG, Arroyo MTK (1999) Ausencia de banco de semillas persistente en Nothofagus pumilio (Fagaceae) en Tierra del Fuego, Chile. Rev Chil Hist Nat $72: 73-82$

Cuevas J (2000) Tree recruitment at the Nothofagus pumilio alpine timberline in Tierra del Fuego, Chile. Ecology 88:840-855

Denny EG, Gerst KL, Miller-Rushing AJ, Tierney GL, Crimmins TM, Enquist CAF, Guertin P, Rosemartin AH, Schwartz MD, Thomas KA, Weltzin JF (2014) Standardized phenology monitoring methods to track plant and animal activity for science and resource management applications. Int J Biometeorol 58:591-601

Donoso C, Donoso P (2006) Nothofagus betuloides (Mirb) Oerst. In: Donoso Zegers C (ed) Las especies arbóreas de los bosques templados de Chile y Argentina: autoecología. Marisa Cuneo Ediciones, Valdivia Chile, pp 411-422

Dreiss LM, Volin JC (2013) Influence of leaf phenology and site nitrogen on invasive species establishment in temperate deciduous forest understories. Forest Ecol Manag 296:1-8

Espelta JM, Cortés P, Molowny-Horas R, Retana J (2009) Acorn crop size and predispersal predation determine inter-specific differences in the recruitment of co-occurring oaks. Oecologia 161:559-568

Frangi JL, Barrera MD, Puig De Fábregas J, Yapura PF, Arambarri AM, Richter L (2005) Ecología de los bosques de Tierra del Fuego. In: Goya JF, Frangi JL, Arturi MF (eds) Investigación en bosques nativos de Argentina. Universidad Nacional de La Plata, Buenos aires, p 88

Frazer GW, Fournier RA, Trofymow JA, Gall RJ (2001) A comparison of digital and film fisheye photography for analysis of forest canopy structure and gap light transmission. Agr Forest Meteorol 109:249-263

Gutiérrez E (1994) Els boscos de Nothofagus de la Terra del Foc com a paradigma de dinámica successional del no-equilibri. Treballs de la SCB 45:93-121

Hertel D, Therburg A, Villalba R (2008) Above- and below-ground response by Nothofagus pumilio to climatic conditions at the transition from the steppeforest boundary to the alpine treeline in southern Patagonia, Argentina. Plant Ecol Divers 1(1):21-33

Ivancich H, Martínez Pastur G, Roig F, Barrera M, Pulido F (2012) Changes in height growth patterns in the upper treeline forests of Tierra del Fuego in relation to climate change. Bosque 33(3):267-270

Kelly D, Koenig WD, Liebhold AM (2002) An intercontinental comparison of the dynamic behavior of mast seeding communities. Popul Ecol 50:329-342

Kon H, Noda T, Terazawa K, Koyama H, Ysaka M (2005) Proximity factors causing mast seeding in Fagus crenata: the effects of resource level and weather cues. Can J Bot 83:1402-1409
Kreps G, Martínez Pastur G, Peri PL (2012) Cambio climático en Patagonia sur. Escenarios futuros en el manejo de los recursos naturales. INTA (ed). Santa Cruz, Argentina, p 100

Leishman MR, Wright IJ, Moles AT, Westoby M (2000) The evolutionary ecology of seed size. In: Fenner M (ed) Seeds: the ecology of regeneration in natural plant communities. CABI Publishing, Wallingford, pp 125-166

Lu H, Mohren GMJ, Ouden J, Goudiaby V, Sterck FJ (2016) Overyielding of temperate mixed forests occurs in evergreen-deciduous but not in deciduous-deciduous species mixtures over time in the Netherlands. Forest Ecol Manage 376:321-332

Martínez Pastur G, Peri PL, Vukasovic R, Vaccaro S, Piriz Carrillo V (1997) Site index equation for Nothofagus pumilio Patagonian forest. Phyton 6:55-60

Martínez Pastur G, Lencinas MV, Peri PL, Cellini JM (2008) Flowering and seeding patterns in unmanaged and managed Nothofagus pumilio forests with a silvicultural variable retention system. Forstarchiv 79:60-65

Martínez Pastur G, Cellini JM, Lencinas MV, Barrera M, Peri PL (2011) Environmental variables influencing regeneration of Nothofagus pumilio in a system with combined aggregated and dispersed retention. For Ecol Manage 261:178-86

Massaccesi G, Roig F, Martínez Pastur G, Barrera M (2008) Growth patterns of Nothofagus pumilio trees along altitudinal gradients in Tierra del Fuego, Argentina. Trees 22(2):245-255

Moore DM (1983) Flora de Tierra del Fuego. Anthony Nelson, England, p 338

Pérez-Ramos IM, Aponte C, García LV, Padilla-Díaz CM, Marañón T (2014) Why is seed production so variable among individuals? A ten-year study with oaks reveals the importance of soil environment. PLoS One 9:e115371. doi:10.1371/journal.pone.0115371

Pretzsch H (2014) Canopy space filling and tree crown morphology in mixedspecies stands compared with monocultures. For Ecol Manage 327:251-264

Promis A, Schindler D, Reif A, Cruz G (2009) Solar radiation transmission in and around canopy gaps in an uneven-aged Nothofagus betuloides forest. Int J Biometeorol 53:355-367

Richardson S, Allen R, Whitehead D, Carswell F, Ruscoe W, Platt K (2005) Climate and net carbon availability determine temporal patterns of seed production by Nothofagus. Ecology 86(4):972-981

Riveros M, Parades MA, Rosas MT, Cardenas E, Armesto J, Arroyo MTK, Palma B (1995) Reproductive biology in species of the genus Nothofagus. Environ Exp Bot 35:519-524

Rodríguez R, Quezada M (2003) Fagaceae. In: Marticorena C, Rodríguez R (eds) Flora De Chile. Universidad de Concepción, Concepción, pp 64-76

Schauber EM, Kelly D, Turchin P et al (2002) Masting by eighteen New Zealand plant species: the role of temperature as a synchronizing cue. Ecology 83:1214-1225

Schoolmaster J (2013) Resource competition and coexistence in heterogeneous metacommunities: many species coexistence is unlikely to be facilitated by spatial variation in resources. Peer J 1:e136. doi:10.7717/peerj.136

Soler R, Martínez Pastur G, Lencinas MV, Peri PL (2010) Flowering and seeding patterns in primary, secondary and managed Nothofagus antarctica South Patagonian forests. New Zeal J Bot 48(2):63-73

Swenson U, Backlund A, McLoughlin S, Hill RS (2001) Nothofagus biogeography revisited with special emphasis on the enigmatic distribution of subgenus Brassospora in New Caledonia. Cladistics 17:28-47

Thiers O, Gerding V (2007) Variabilidad topográfica y edáfica en bosques de Nothofagus betuloides (Mirb) Blume, en el suroeste de Tierra del Fuego. Chile. Rev Chil Hist Nat 80:201-211

Torres AD, Cellini JM, Lencinas MV, Barrera MD, Soler R, Díaz-Delgado R, Martínez Pastur G (2015) Seed production and recruitment in primary and harvested Nothofagus pumilio forests: influence of regional climate and years after cuttings. For Syst 24:1-11

Yasaka M, Terazawa K, Koyama H, Kon H (2003) Masting behavior of Fagus crenata in northern Japan: spatial synchrony and predispersal seed predation. Forest Ecol Manage 184:277-284 